(1) Para melhor compreensão ver: MARTÍN-BARBERO, Jesús. Dos meios às mediações: comunicação, cultura e hegemonia. Rio de Janeiro: UFR, 1997.

El proyeto: produción, composición $y$ "usos" del melodrama televisivo.

In: MARTÍN-BARBERO, Jesús; MUNÕZ, Sonia. Televisión y melodrama. Colômbia: Tercer Mundo Editores, 1992.

(2) NASCIMENTO, Marta Rocha. Globo Rural e cotidiano em

Sapucaia: estudo de recepção do programa Globo Rural pelos pequenos produtores rurais de Sapucaia, Pernambuco. Recife, 1999. Dissertação (Mestrado em Administração Rurale Comunicação Rural) Universidade Federal Rural de Pernambuco. (3) SANTOS, Maria Salett Tauk; et alli. Duas faces da mesma reforma agrária: estudo de recepção das mensagens da Comissão Pastoral da Terra no Engenho Gaipió. Recife: CMARCR/UFRPE, 1998. (mimeo.).

(4) SANTOS, Maria Salett Tauk. Igreja e pequeno produtor rural: a comunicação participativa no programa CECAPAS/SERTA. São Paulo: 1994. Tese (Doutorado em Ciências da Comunicação) Escola de Comunicação e Artes, Universidade de São Paulo. (5) É Orozco Gómez quem sinaliza a contribuição de Martín Serrano aos estudos das mediações culturais: "Manuel M. Serrano habla de una mediación de tos medios de comunicacion. Toda su teorización

Maria Salett Tauk Santos é doutora em Ciências da Comunicação pela ECA-USP e professora da Universidade Federal Rural de Pernambuco. Marta Rocha do Nascimento é mestre em Administração Rural e Comunicação Rural pela Universidade Federal Rural de Pernambuco.

Maria Salett Tauk Santos e

Marta Rocha do Nascimento

\title{
Desvendando o mapa noturno: análise da perspectiva das mediações nos estudos de recepção
}

Tomando como referência três estudos de recepção desenvolvidos em contextos populares, este texto faz uma análise da perspectiva das mediações culturais nos estudos de recepção demonstrando que o modelo das múltiplas mediações não se constitui em uma baliza que o pesquisador se apropria para explicar um determinado fenômeno na audiência, tratase antes de uma construção que permite a cada objeto de estudo revelar ao pesquisador as mediações "por excelência" intervenientes em cada processo de comunicação.

Desde os escritos de Jesús MartinBarbero $^{1}$ propondo a perspectiva das mediações culturais quando se trata de compreender as culturas populares no capitalismo, poucas reflexões têm sido feitas no sentido de analisar a pertinência e o alcance interpretativo dessa teoria, quando aplicada à pesquisa empírica.

Portanto, o objetivo desse texto é fazer uma reflexão da perspectiva das mediações culturais aplicada a estudos empíricos em contextos populares. A intenção é demonstrar que as mediações não são balizas prontas que o pesquisador se apropria para explicar um determinado fenômeno. Antes, trata-se de uma construção metodológica na qual o próprio objeto revela ao pesquisador quais as mediações que estão interferindo no processo.

Nesse sentido, tomaremos três estudos de recepção a partir dos quais demonstraremos como em cada um deles foram as circunstâncias empíricas do objeto que revelaram ao pesquisador as mediações intervenientes/interferentes em cada uma das pesquisas analisadas.

Trata-se de três estudos de caso que tiveram como ponto de partida o modelo das múltiplas mediações concebido por Guilhermo Orozco Gómez Gómez. Esses estudos foram desenvolvidos em contextos populares envolvendo pequenos produtores rurais no estado de Pernambuco. O primeiro refere-se a um estudo de recepção do programa Globo Rural; ${ }^{2}$ o segundo trata-se de um estudo de recepção das mensagens da Comissão Pastoral da Terra -CPT- em assentamento de reforma agrária; ${ }^{3}$ e o terceiro constitui um estudo de recepção das mensagens de uma ONG ligada a Igreja Católica-CECAPAS/SERTA. ${ }^{4}$

\section{A perspectiva das} mediações culturais

As mediações culturais se constituem num modelo ou perspectiva de compreensão da relação entre cultura e meios de comunicação, dentro da pesquisa de recepção. O conceito de mediações foi mencionado pela primeira vez pelo investigador Manuel Martín Serrano ${ }^{5}$, e posteriormente por Jesús Martín-Barbero, que aplicou parte da concepção de Serrano a sua visão e vem desenvolvendo, nos últimos anos, a idéia de se passar dos meios para as mediações, ou seja, investigar os processos de constituição do massivo a partir das transformações das culturas populares. Esse deslocamento se dá gra- 
ças à aproximação cultura/comunicação.

Martín-Barbero consegue, a partir da sua concepção de mediação, liberar a comunicação do espaço restrito dos meios para o espaço da cultura, mostrando que as mediações têm uma relação direta com o processo de comunicação. Uma vez que esse não se estabelece de maneira linear e simétrica, o que existe é uma relação mediatizada pelos contextos em que o processo de comunicação se estabelece. ${ }^{6}$ Nesse sentido, desenvolvemos a concepção de que mediações podem ser compreendidas como sendo um conjunto de fatores que estruturam, organizam e reorganizam a percepção e a apropriação da realidade social, por parte do receptor.

Na compreensão de Martín-Barbero, as mediações se manifestam em práticas concretas. Ele salienta três que considera especialmente importantes para entender a comunicação e a cultura: a sociabilidade, a ritualidade e a tecnicidade. A sociabilidade diz respeito às práticas cotidianas de todos os sujeitos sociais na negociação do espaço de uns com os outros; a ritualidade está relacionada às rotinas, que determinam de certa maneira a produção de sentido e a produção cultural que se dá através delas; a tecnicidade tem a ver com as tecnologias da informação, com os meios de comunicação, sendo o terceiro âmbito de onde se manifesta a mediação cultural. ${ }^{7}$

Orozco Gómez traz a teoria de Martín Barbero sobre as mediações culturais para o nível empírico, uma vez que ele afirma não ter Martín-Barbero elaborado um conceito de mediações em termos mais concretos. Para Orozco Gómez, é tarefa das múltiplas mediações explorar a ritualidade, a tecnicidade e a sociabilidade propostas por Martín-Barbero no universo empírico. Nesse sentido, ele desenvolve o modelo das mediações múltiplas que passa necessariamente por um enfoque integral da recepção levando a concepção do processo de recepção como um processo complexo, multidimensional e multi direcional, e queidas num contexto ou ambiente deter- sofre a intervenção e o condicionamento de uma série de situações, entre outras, do contexto cultural, político, histórico. ${ }^{8}$

A preocupação de Orozco Gómez passa pelo desenvolvimento de um marco conceptual que não esteja sustentado em dicotomias, tais como: macro-micro, emissor-receptor. Para superar a racionalidade entre contextos sociais macro e micro, ele sugere adotálos como fontes de mediação. No modelo proposto por Orozco Gómez encontramos uma série de fontes de mediações que são fundamentais para a compreensão do processo de recepção: cultura, política, economia, classe social, gênero, idade, etnicidade, os meios, as condições situacionais e contextuais, as institucionais e os movimentos sociais. Essas fontes podem se originar da mente do sujeitoreceptor, em suas emoções e suas experiências. Essas fontes de mediações podem mediar outras fontes. ${ }^{9}$

Para efeito de classificação Orozco Gómez propõe, a partir do caráter múltiplo das mediações, quatro grupos: individual ou cognoscitiva, situacional, institucional e videotecnológica ou massmediática.

A mediação individual, Orozco Gómez define como sendo a que provém da nossa individualidade enquanto sujeitos sociais, membros de uma -cultura. Somos sujeitos cognoscentes e comunicativos. Nesse sentido, existem certos esquemas mentais ou repertórios que são responsáveis pelo sentido que damos a uma nova informação.

A mediação institucional se manifesta a partir da participação do indivíduo em determinadas instituições como a família, a igreja, a escola, o trabalho. As instituições utilizam diversos recursos para implementar sua mediação, como o poder e as regras, e podem competir entre si.

A mediação contextual refere-se a todas as características que estão insedas num contexto ou ambiente deter- es recionalista e sistémica (no es el caso de Martín-Barbero ni et de modelo de la mediación). Serrano concibe los sistemas: el sistema social y el sistema de medios de comunicación, y dice: 'una de las funciones del sistema de comunicación es mediar entre el sistema social y la sociedad'. Esta mediación el la entiende como de dos tipos fundamentales: mediación estructural y mediación cognitiva de los medios de comunicación. La mediación cognitiva, según Serrano, tiene que ver con la función que ejercen los medios en seleccionar de los acontecimientos sociales aquellos que merecen ser dados a conocer

a la sociedad en su consumos, através de los medios de comunicación, es decir: es una mediación fundamentalmente ideológica, através de la cual se define lo que es importante, relevante y oportuno que la sociedad conozca. Por mediación estuctural, lo que entiende Serrano es aquella función de los medios que, debido a su peculiaridad,

imprimem a la selección y presentación de los seleccionado: tiene que ver com las características intrínsecas." A esse respeito ver: OROZCO, Gómez. La investigación en comunicación desde la perspectiva qualitativa. México: IMDEC, 1997.

(6)MARTÍN-BARBERO, Jesús. Dos meios às mediacõos...

(7) Idem, Ibidem.

(8) OROZCO, Gómez. Apud. JACKS, Ni/da A. Pesquisa de recepção: investigadores, paradigmas, contribuições latinoamericanas. In: INTERCOM Revista Brasileira de Comunicação. São Paulo, Vol.XVI, n. 1, jan./jun. 1993, p. 23. 
minado, como idade, sexo, ocupação; a situacional, por sua vez, está relacionada com a situação em que a recepção se processa, ou seja, como o receptor se encontra na hora da recepção. Nesse sentido, vale ressaltar que a situação em questão não está desconectada do papel social do indivíduo no seu contexto, questão que ficará mais clara quando analisarmos o estudo de recepção do programa Globo Rural; a mediação massmidiática é a que emana do próprio meio, englobando a intencionalidade do emissor. ${ }^{10}$

Os estudos de recepção que objetivam explicar qual é a relação estabelecida entre as culturas populares e a cultura hegemônica a partir da perspectiva das mediações culturais, como é o caso dos três estudos que serão analisados mais adiante, consideram o estudo do cotidiano como sendo fundamental para a análise da recepção, na medida em que é no espaço do cotidiano que as mediações se explicitam.

Para Mauro Wilton de Sousa, "a perspectiva de que o cotidiano possa ser o espaço onde os processos simbólicos são elaborados e reelaborados em si mesmo e a partir das relações que tem com outros processos simbólicos, faz do cotidiano como tal o espaço mesmo de compreensão do processo simbólico e das relações de poder que aí se imbricam". ${ }^{11}$

No que diz respeito à questão metodológica do modelo das múltiplas mediações, Orozco Gómez argumenta que é necessário adotar uma metodologia não ortodoxa, fazendo-se o uso combinado de métodos qualitativos e quantitativos. Esclarece, ainda, que a combinação de metodologias deverá realizar-se com uma perspectiva histórica que permita contextualizar a explicação. A investigação proposta por esse autor se constrói a partir da relação dialética entre investigador e objeto de estudo, na qual se assumem explicitamente distintas determinações do investigador e dos sujeitos da investigação. ${ }^{12}$

Orozco Gómez salienta que a metodologia das múltiplas mediações está em processo de se consolidar. Daí a importância de se desenvolver experiências empíricas. Ë nesse sentido de considerar uma perspectiva em construção que o Curso de Mestrado em Administração Rural e Comunicação Rural - CMARCR/UFRPE vem desenvolvendo uma linha de pesquisa de recepção em contextos populares. A linha de pesquisa de recepção do CMARCR não se limita a processos diretamente ligados às mídias. A recepção é entendida como um processo onde existe um contrato de comunicação proposto por organizações governamentais, organizações não governamentais ou a mídia e uma determinada população.

Nessa perspectiva foram desenvolvidos estudos de recepção envolvendo a relação TV-audiência - o caso Globo Rural; estudo de recepção das mensagens de uma organização não governamental - o CECAPAS/SERTA, por pequenos agricultores; e um estudo de recepção das mensagens da Comissão Pastoral da Terra - CPT, vinculada à Igreja Católica. Nos três casos as audiências são compostas por pequenos produtores rurais de Pernambuco.

Tomando como referência esses estudos, demonstraremos como em cada um deles foi a audiência quem determinou as mediações que interferiram no processo. Em outras palavras, são as circunstâncias do objeto que oferecem as pistas para que o pesquisador capte a mediação "por excelência", isto é, aquela ou aquelas cuja interferência afeta de maneira singular o processo de comunicação. Nessa perspectiva, a mediação é considerada como algo construído em re cada caso. A tarefa do pesquisador nesse modelo é a de construir um intinerário original, como quem desvenda o mapa noturno de que fala 
Martín-Barbero.

Desvendando o Mapa Noturno

Apresentaremos uma síntese dos três estudos selecionados analisando especificamente as mediações "por excelência" identificadas em cada um desses estudos.

Globo Rural e cotidiano em Sapucaia: estudo de recepção do programa Globo Rural pelos pequenos produtores rurais de Sapucaia, Bom Jardim

Este estudo de recepção de televisão buscou compreender como se estabeleciam as relações entre a cultura massiva/hegemônica - representada pelo programa Globo Rural - e as culturas populares - representadas pelos pequenos produtores rurais de Sapucaia, Bom Jardim, Pernambuco. Especificamente, objetivou-se compreender os "usos"13 que esses pequenos produtores faziam da proposta do Globo Rural, no seu cotidiano. ${ }^{14}$

$\mathrm{O}$ estudo evidenciou, dentre as conclusões, que o Globo Rural possui uma proposta jornalística combinada a uma proposta de Comunicação Rural desenvolvida na perspectiva difusionista-modernizadora; e que os pequenos produtores rurais de Sapucaia, objetivando incorporar-se à lógica massiva/hegemônica proposta pelo Globo Rural, reconvertiam intencionalmente as suas práticas culturais, o que se materializava no universo do trabalho e nos demais domínios de suas vidas. Essas reconversões sofriam a influencia das mediações culturais desses produtores.

No estudo exploratório dessa investigação observou-se que o gênero e a ocupação poderiam interferir nos "usos" que esses receptores faziam das mensagens do Globo Rural. O estudo evidenciou que o gênero e a ocupação deveriam ser analisados de forma combinada, uma vez que em Sapucaia grande parte da ocupação era determinada pelo sexo. Nesse sentido, o gênero e a ocupação foram consi- derados as mediações "por excelência", dessa pesquisa.

Gênero e Ocupação: mediações indissociáveis

A pesquisa demonstrou - através das análises - que as mulheres, na cultura do meio rural nordestino, não assistem ao programa Globo Rural da mesma forma que os homens - do começo ao fim -, pois desempenham tarefas paralelas, tarefas essas atribuídas pelo sexo (afazeres domésticos, cuidar das crianças...).

O gênero vai fazer diferença também na hora do acesso ao desenvolvimento intelectual. Os homens tinham liberdade para estudar na sede do município desde os doze anos de idade, uma vez que a escola existente no sítio Sapucaia só contemplava o ensino até a última série do primeiro grau. As mulheres, por sua , vez, só recebiam autorização para voltar a estudar quando completavam quinze anos, e nesta idade a maioria estava mais preocupada em constituir suas próprias famílias, demonstrando pouca motivação para continuar os seus estudos.

Esse fato influi no processo de recepção de televisão e nos "usos" que a população de Sapucaia faz das mensagens do Globo Rural. Os homens, que tinham a possibilidade de continuar estudando, demonstraram ter mais facilidade de compreender as mensagens do programa. As mulheres, no entanto, desenvolviam a percepção do programa como sendo uma atividade dos homens, uma vez que, segundo elas, são os homens que decidem o que fazer na produção, apesar de serem sempre chamadas para assistir ao Globo Rural quando aparecia algo "diferente", "inusitado", "curioso" como o caso do "bode reprodutor que dava leite".

A análise da ocupação, por sua vez, evidenciou que o trabalho desenvolvido por esses produtores "condicionava" ou "influenciava" os "usos" que eles faziam das mensagens do Globo Rural.
(12) Idem, ibidem.

(13) "usos", compreendidos a partir da perspectiva dos "usos sociais dos meios", conhecida como a corrente latino-americana concebida por Jésus MartínBarbero, onde em síntese busca-se saber o que fazem as pessoas com as mensagens dos meios de comunicação na sua realidade cotidiana.

(14) Como referencial teórico foram utilizados os estudos mais recentes de Comunicação Rural os estudos de recepção a partir das mediações culturais - que contemplam a comunicação relacionada com a cultura, em contextos populares. As explicações desse estudo fundamentaram-se na perspectiva teóricometodológica concebida por Jesús Martín-Barbero sobre os usos sociais dos meios. Tendo como categorias de análise: o consumo cultural - a partir dos estudos de Néstor Garcia Canclini; e as mediações culturais - a partir do modelo das mediações múltiplas desenvolvido por Guilhermo Orozco Gómez. Tratou-se de um estudo de caso com amostra intencional composta por 11 famílias. Foram utilizadas técnicas combinadas de coleta de dados: observação direta, observação etnográfica, entrevistas semi-estruturadas e pequena história de vida. 
A atividade agrícola desenvolvida por eles contemplava todos os membros da família, independente de sexo e de idade, ocupando uma jornada de 10 a 12 horas diárias de segunda a sexta-feira e de aproximadamente 06 horas aos sábados e domingos, traduzindo dessa forma a importância que ocupava no cotidiano desses produtores.

No trabalho agrícola, as mulheres de Sapucaia são consideradas iguais aos homens, isto é, têm as mesmas funções e responsabilidades. A diferença se estabelece no trabalho doméstico, considerado da competência exclusiva das mulheres. Daí elas desenvolverem uma jornada dupla, ou seja, além do trabalho na agricultura, são responsáveis pelas tarefas domésticas, a não ser em raras exceções (quando estavam doentes ou viajando).

Através da análise do sexo e da ocupação pôde-se perceber que os produtores do Sítio Sapucaia assistem ao programa Globo Rural coletivamente com suas famílias, uma vez que possuem apenas um aparelho de televisão. As mulheres, por sua vez, não se dedicam à recepção do programa da mesma forma que os homens, elas dividem a audiência ao programa com as tarefas domésticas, como cuidar da arrumação da casa, fazer o almoço, cuidar de crianças.

O fato da mulher ver o Globo Rural desempenhando outras tarefas remete à compreensão de que a mediação situacional não se esgota no ato de assistir a TV - ou seja, não é ocasional, é uma mediação que denota a maneira como aquela população estrutura sua vida no cotidiano e que tem uma implicação com o papel reservado para a mulher nessa sociedade. No trabalho, ela é tida como igual, mas no doméstico ocupa uma posição diferenciada, uma vez que este é tido como sendo um universo sagrado para a mulher.

Podemos perceber que é da combinação das mediações contextuais de gênero e ocupação que nasce a mediação "por excelência”, nesse estudo. Assim, do fato de ser mulher agricultora no contexto popular rural do Nordeste do Brasil, e mais toda a carga cultural que isso significa, é que se constitui a mediação que condiciona os "usos" do Globo Rural em Sapucaia.

Duas Faces da Mesma Reforma Agrária: estudo de recepção das mensagens da Comissão Pastoral da Terra no Engenho Gaipió

O estudo de recepção da política de comunicação da Comissão Pastoral da Terra (CPT) para a reforma agrária ${ }^{15}$, teve como objetivo analisar as representações sociais de duas realidades distintas, a dos antigos moradores e a da população que ocupou parte do Engenho Gaipió e que se encontrava lá acampada, quanto às mensagens da CPT a respeito da reforma agrária. O estudo tomou como base a concepção de Martín-Barbero acerca das mediações e, seguindo essa perspectiva, utilizou o modelo das múltiplas mediações proposto por Guilhermo Orozco Gómez.

A idéia que norteou o trabalho foi a de que as representações sociais eram construídas por meio de trocas simbóIćas na vivênciả do espaço cultural. O que se observou, portanto, diz respeito ao conhecimento construído pelos dois grupos diante de suas especificidades culturais. Apesar de estarem na mesma fase jurídica do processo de reforma agrária - a de assentamento - as populações em estudo se configuravam de forma diversa, com aspirações e idéias próprias em relação à situação em que se encontravam.

Devido à peculiaridade dessas duas realidades, surgiu a necessidade de se criar uma modalidade de mediação: a da procedência, dentro da categoria de referência. Procedência foi definida como a vivência diferenciada de cada grupo antes do assentamento. Significa procedência não como origem geográfica, mas como origem históricopolítica, a qual determina que em um 
mesmo espaço temporal os dois grupos vivam distintas temporalidades.

Assim, o fato da população do Engenho Gaipió desenvolver à época do assentamento uma relação de trabalho próxima à da sociedade patriarcal, predominante na Zona da Mata canavieira de Pernambuco, distingue fundamentalmente o imaginário dessa população em relação ao imaginário dos acampados no Engenho: população esta que é heterogênea, nômade, sem vínculo empregatício, sem moradia, que saíra de acampamentos improvisados na beira das rodovias para ocupar as terras de Gaipió sob a liderança da Comissão Pastoral da Terra.

\section{Procedência histórico-política:}

\section{a dupla face da reforma agrária}

A análise das representações sociais das mensagens da CPT acerca da reforma agrária evidenciou diferentes formas de produção de sentido por parte dos grupos estudados. Ambos os grupos demonstraram compreender o papel de orientação da CPT, tendo alguns inclusive sentido a Pastoral como um movimento, tal a força da assessoria da entidade em seus imaginários. No entanto, valores diferenciados foram atribuídos a essa orientação. Os moradores, durante as reuniões, pareciam se interessar mais por questões práticas como custeio e de limitação dos lotes, ao passo que os acampados demonstraram maior interesse pelas questões ligadas à organização da luta e exercício da cidadania.

A reforma agrária era um fato novo nas vidas dos moradores de Gaipió, se configurando numa percepção em construção. Pôde-se observar que eles começavam a vislumbrar a reforma agrária como um novo modo de subsistência. Os acampados, por sua vez, internalizavam mais os discursos da CPT, e relacionavam a reforma agrária com a utopia da transformação da sociedade. Para os acampados, o processo da reforma agrária se configurava numa forma de exercer a sua cidadania e realizar seus sonhos de consumo simbólico e material.

Nesse sentido, a mediação da procedência tomou-se a mediação "por excelência" dessa investigação, configurando-se no espaço privilegiado para compreender-se as representações sociais dos dois grupos acerca das mensagens da CPT, ou seja, as temporalidades presentes no cotidiano desses receptores.

\section{Igreja e Pequeno Produtor Rural: a comunicação participativa no programa CECAPAS/SERTA}

Trata-se de um estudo de recepção das mensagens do Centro de Capacitação e Acompanhamento aos Projetos Alternativos - CECAPAS, ONG vinculada à Igreja Católica de Pernambuco pelos pequenos produtores rurais de Pernambuco, tomando a participação popular e o consumo como pontos centrais da análise. A pesquisa se desenvolveu dentro da abordagem teórica de Néstor Garcia Canclini, que estuda as culturas populares na contemporaneidade de forma relacionai à cultura hegemônica transnacional. O consumo foi o espaço escolhido para observação da participação dos pequenos produtores rurais do Programa, por ser considerado o espaço-chave onde se manifes-

- tam as culturas no cotidiano: as mensagens da cultura alternativa, propondo uma tecnologia adaptada às condições de pobreza campesina, e das mensagens da cultura hegemônica, propondo tecnologias e hábitos de consumo modernos como saída para o desenvolvimento do campo.

A participação do pequeno produtor no Programa se dava em um espaço conflituoso. Concomitantemente às mensagens do Programa esses agricultores achavam-se historicamente expostos às mensagens da cultura transnacional, que é hegemônica, via serviços de Extensão Rural, a mídia e outros meios que defendiam a modernização 
como saída para o desenvolvimento do setor agrícola.

\section{Aspirações de Consumo: participação reticente}

A análise da participação dos agricultores no Programa CECAPAS evidenciou que é no espaço do imaginário, ou seja, das expectativas de consumo, onde se materializa a incompatibilidade no uso da proposta do Programa. A tecnologia alternativa está perto das condições reais de existência desses agricultores mas distante, no plano simbólico, de suas aspirações de consumo. Desejam incorporar os apelos modernizadores como forma de sentirem integrados na ordem hegemônica. Isso contribui para a reticente participação da população de pequenos agricultores envolvidos no Programa.

Esses agricultores, ao mesmo tempo em que estavam expostos às mensagens do CECAPAS, estavam também expostos à influência da cultura hegemônica que suscita hábitos de consumo de tecnologias modernas tanto no trabalho como nos demais domínios de suas vidas. Ao não encontrarem respostas para as suas aspirações de consumo erigidas a partir das mensagens modernizadoras hegemônicas, os pequenos produtores rurais refuncionalizam os usos das propostas do CECAPAS. Assim, os agricultores emprestam um significado diferente à participação no Programa no sentido de adaptá-la às suas necessidades cotidianas imediatas que oscila entre o lúdico e o religioso. Estes significados não são antagônicos em relação à proposta original de participação política no Programa. Entretanto, na medida em que se distanciam do sentido original da luta proposta pelo CECAPAS, os agricultores tomam a sua participação reticente em relação aos objetivos do Programa, fato este que contribui conseqüentemente para o avanço lento dessa luta pois, no lugar da produção, colocam a reza; no lugar da participação política, colocam o lazer.

Nesse sentido, a mediação "por excelência" desse estudo foi a aspiração de consumo, na medida em que foi nesse espaço que se materializou a incompatibilidade entre a proposta do programa CECAPAS as aspirações da população de pequenos produtores rurais.

Os estudos analisados evidenciaram que são as circunstâncias do objeto que sinalizam as mediações que o pesquisador deve considerar para explicar um determinado fenômeno que norteia o objeto que ele pretende construir e explicar.

A perspectiva das multimediações proposta por Orozco Gómez é um modelo que oferece excelentes pistas quando se trata de analisar a recepção enquanto lugar onde o processo da comunicação adquire sentido. Entretanto, cabe ao pesquisador tomá-lo apenas como grid de largada, pois ao longo do estudo é o pesquisador que irá desvendar as mediações que interferem no processo da comunicação como quem desvenda um mapa noturno. 


\section{Bibliografia do artigo}

OROZCO GÓMEZ, Guilhermo. La investigación en comunicación desde la perspectiva qualitativa. México: IMDEC, 1997.

, Recepción televisiva: tres aproximaciones y una

razón para su estudio. In: Cuadernos de Comunicación y Practicas Sociales. México: Universidad Iberoamericana, 1991.

JACKS, Nilda A. Pesquisa de recepção: investigadores, paradigmas, contribuições latino-americanas. In: INTERCOM Revista Brasileira de Comunicação. São Paulo, Vol.XVI,n. 1,jan./jun. 1993.

MARTÍN-BARBERO, Jesús. Dos meios às mediações: comunicação, cultura e hegemonia. Rio de Janeiro: UFRJ, 1997. , El proyeto: produción, composición y "usos" del melodrama televisivo. In: MARTÍN-BARBERO, Jesús. ; MUNÕZ, Sonia. Televisión y melodrama. Colômbia: Tercer Mundo Editores, 1992.

NASCIMENTO, Marta Rocha. Globo Rural e cotidiano em Sapucaia: estudo de recepção do programa Globo Rural pelos pequenos produtores rurais de Sapucaia, Pernambuco. Recife, 1999. Dissertação (Mestrado em Administração Rural e Comunicação Rural) Universidade Federal Rural de Pernambuco.

SANTOS, Maria Salett Tauk. Igreja e pequeno produtor rural: a comunicação participativa no programa CECAPAS/SERTA. São Paulo: 1994. Tese (Doutorado em Ciências da Comunicação) Escola de Comunicações e Artes, Universidade de São Paulo.

. et alli. Duas faces da mesma reforma agrária:

estudo de recepção das mensagens da Comissão Pastoral da Terra no Engenho Gaipió. Recife: CMARCR/UFRPE, 1998. (mimeo.).

SOUSA, Mauro Wilton. A rosa púrpura de cada dia: trajetória de vida e cotidiano de receptores de telenovelas. São Paulo, 1986. Tese (Doutorado em Ciência da Comunicação). USP, ECA, p. 96. 